\title{
Notebook
}

\section{Jacobsen Fellowships and Royal Institute of Philosophy Bursaries}

In accordance with the deed of trust made by the benefactor Mr. Jens Jacobsen, The Royal Institute of Philosophy is pleased to offer for the academic year 2010-2011 up to seven Jacobsen Fellowships for research in certain fundamental parts of philosophy. The Fellowships, of $£ 8,000$ each, will be for one year.

The parts of philosophy are: speculative metaphysics, critical metaphysics, the philosophy of mind, epistemology, philosophical logic, philosophy of life, determinism, the nature of life, evolution, moral philosophy, political and social philosophy. This list is in accordance with the philosophical interests of Mr. Jacobsen.

In addition, postgraduates are offered up to eight Royal Institute of Philosophy Bursaries for 2010-2011. The bursaries, of $£ 2,500$ each, are also for one year but carry no restrictions as to area of study. Candidates may be considered for both Fellowships and Bursaries, but if awarded a Fellowship a student will not also be offered a Bursary. The Royal Institute of Philosophy, in accord with its own remit, seeks candidates whose work, while rigorous, avoids needless technicality and is in the tradition of philosophy as a humane discipline.

Please note that the following conditions apply to these awards:

1. Applicants must have already completed at least one year of work for a higher degree in philosophy in a UK University by the start of the 2010-2011 academic year. However preference may well be given to applicants nearing the end of a course of study leading to a doctorate.

2. Applicants must be engaged in full-time study for a higher degree in philosophy at a UK institution while in receipt of any award during the academic year 2010-2011.

3. No one will be awarded either a Fellowship or a Bursary who is in receipt of any other award for the academic year 2010-2011 of over $£ 3,000$. In view of this restriction, The Royal Institute of Philosophy will be unable to make its final decisions prior to the announcement of the British Academy/AHRB studentships in September 2010.

Candidates must arrange for two academic referees, at least one from the institution at which they are currently studying, to write on their behalf direct to The Royal Institute of Philosophy. Application forms are available at www.royalinstitutephilosopy.org. Applications and references should be sent to Dr. James Garvey, The Royal Institute of Philosophy, 14 Gordon 


\section{Notebook}

Square, London WC1H OAR, to arrive no later than 11 June 2010. Applications and letters by post only, please.

\section{Conference 2010: Human Nature}

The 2010 Royal Institute of Philosophy Conference will be on Human Nature and shall take place at Oxford Brookes University, 15-17th June. The conference shall aim to address key issues and taboos surrounding the theme of human nature by bringing together philosophers working in a multitude of areas including the philosophy of cognitive science, evolutionary psychology, the philosophy of biology, psychoanalysis, ethics, developmental psychology, philosophy of mind and action, the philosophy of psychology, and the history of philosophy. Conference speakers include John Cottingham, Tim J. Crow, John Dupre, Hans-Johann Glock, P.M.S. Hacker, Wolfram Hinzen, Peter Kail, Sarah Patterson, Richard Samuels, and Kim Sterelny. For further details please contact Constantine Sandis (csandis@brookes.ac.uk).

\section{Conferences 2009 and 2010}

Each year the Royal Institute of Philosophy offers sponsorship of up to $£ 3,000$ for a conference hosted by a university department of philosophy. Philosophy departments are now invited to submit proposals for conferences in 2009 and 2010.

Proposals should be sent to Dr. James Garvey at The Royal Institute of Philosophy, 14 Gordon Square, London WC1H 0AR to arrive no later than $1^{\text {st }}$ April 2008. The Institute's Conference Committee would wish to make a choice of venues as soon as possible after that date. In coming to a decision, the committee will have regard to previous locations and topics (listed below) as well as the suitability of the topic proposed for laypeople and professional philosophers. When making a proposal, please indicate whether it would be for 2009 or 2010 or whether either year would be possible.

Since 1986, the proceedings of conferences have been published by arrangement with the Cambridge University Press as supplements to the Institute's journal, Philosophy.

\section{Past and Forthcoming Conferences}

1971 Canterbury: Philosophy of Psychology

1973 Exeter: Philosophy of Education

1975 Lancaster: Reason and Religion

1977 Norwich: Philosophy of the Social Sciences

1979 Lancaster: Law, Morality, and Rights 
1981 Keele: Space, Time and Causality

1983 Lancaster: Philosophy and Its Past

1985 Bristol: Philosophy and the Visual Arts

1986 Belfast: Moral Philosophy

1987 York: Philosophy and Medical Welfare

1989 Glasgow: Explanation

1990 Lampeter: Human Beings

1991 Liverpool: Philosophy, Religion, and the Spiritual Life

1992 Birmingham: Philosophical Issues in Cognitive Science

1993 Cardiff: Philosophy and the Natural Environment

1994 Bradford: Philosophy and Technology

1995 Ulster: Philosophy and Pluralism

1996 Reading: Thought and Language

1997 St Andrews: Philosophy and Public Affairs

1999 Edinburgh: Naturalism, Evolution and Mind

2000 LSE: Time, Reality and Experience

2001 Manchester: Philosophy and the Emotions

2002 Oxford: Agency and Action

2003 Durham: The Philosophy of Need

2004 Cambridge: Philosophy and Economics

2005 Hertfordshire: Narrative and Understanding Persons

2006 Leeds: Developments in Contemporary Metaphysics

2007 UCL: Immanuel Kant: From Philosophy to Physics

2008 Liverpool: Philosophy as Therapeia: Perspectives from India and Europe

\section{Conditions of Sponsorship}

1. Conference funding is for speakers' expenses, general administration and advertising costs. This would, of course, include accommodation and meals for the speakers where appropriate, but not a general hospitality fund.

2. The topic agreed for the conference may not be changed except by consent of the Director of the Institute. The detailed arrangements of the conference programme are, however, entirely at the discretion of the host department.

3. The host department is expected to produce the proceedings of the conference ready for publication in the year following the conference, both in manuscript form and in a suitable electronic format. An editor of the volume should be appointed as well as a conference organiser although one person might do both jobs. The royalties from the sale of the volume will accrue to the Institute. However, an honorarium of $£ 500$, additional to the subvention paid to the department, will be paid to the editor of the volume. 


\section{Notebook}

It should be made clear to speakers at the time they are invited that it is intended that the papers presented at the conference will be suitable for publication as a special supplement to Philosophy. The host department is expected to ensure that papers selected for publication are of the high professional standard, and delivered in the house style, of papers appearing in the Institute's journal.

4. The conference must be known and advertised as a Royal Institute of Philosophy Conference. The Editor of Philosophy will be pleased to accept a call for papers (if this is envisaged) and an advertisement of the programme for the conference. It is expected that the conference will be widely advertised.

5. It is assumed that the Institute will be the main sponsor of the conference, though it may be appropriate to look for additional financial assistance elsewhere. The Institute must be a consenting party to any co-sponsoring arrangement and reserves its right to withdraw sponsorship.

\section{Annual Lecture}

This year's Annual Lecture will be given by Ned Block at $5.30 \mathrm{pm}$ on $5^{\text {th }}$ March 2010 in the New Theatre, East Building, LSE, Houghton Street, London, WC2. His talk is called, 'Attention and Mentalism'. This lecture is free and open to the public. You are advised to arrive early to be sure of a seat. No reservations can be taken. 